\title{
Monetary Policy Independence and Bond Yield in Developing Countries
}

\author{
Cep Jandi ANWAR ${ }^{1}$, Indra SUHENDRA ${ }^{2}$
}

Received: August 01, 2020 Revised: September 22, 2020 Accepted: October 05, 2020

\begin{abstract}
This paper investigates the impact of monetary policy independence shock on bond yield by allowing for heterogeneous coefficients in the model based on panel data for 19 developing countries using quarterly data from 1991 to 2016. First, we estimate the model using conventional panel VAR estimation with the assumption of homogeneous coefficients across countries. Second, by performing Chow and Roy-Zellner tests to check the homogeneity assumption, we find that the assumption does not hold in the model. Third, we apply a meangroup estimation for panel VAR as a solution for heterogeneity panel model. The results reveal that central bank independence is effective in reducing bond yield with the maximum at period 6 after the shock. Shock one standard deviation bond yield has a negative effect on consumption and investment. We determine that central bank independence has a contradictory effect on real activity; a negative effect on consumption but a positive influence on investment for the first two years after the shock. Additionally, we split our sample into three groups to make the subgroups pool. Our empirical result shows that monetary policy independence shock reduces bond yield. Meanwhile, the response of economic activity to bond yield varies for all three groups.
\end{abstract}

Keywords: CBI, Bond Yield, Panel VAR, Poolability Test, Mean Group Estimation

JEL Classification Code: E58, E61, G12

\section{Introduction}

The response of bond yields to central bank reforms is a topic of great interest to financial market players and central bankers. Central bank reforms involve institutional changes by amending statute law of central banks to generate significant institutional strengthening (Carstens et al., 2005; Nurbayev, 2015). As a result of the reforms, the central banks become more independent from government interference to produce a credible and predictable monetary policy. Kuttner (2001) states that bondholders are concerned

${ }^{1}$ First Author and Corresponding Author. Assistant Professor, Department of Economics and Development Studies, Universitas Sultan Ageng Tirtayasa, Banten, Indonesia [Postal Address: Jalan Raya Jakarta Km.4 Pakupatan Serang City, Banten, 42118, Indonesia] Email: cepjandianwar@untirta.ac.id

${ }^{2}$ Assistant Professor, Department of Economics and Development Studies, Universitas Sultan Ageng Tirtayasa, Banten, Indonesia. Email: indras_23@untirta.ac.id

(c) Copyright: The Author(s)

This is an Open Access article distributed under the terms of the Creative Commons Attribution Non-Commercial License (https://creativecommons.org/licenses/by-nc/4.0/) which permits unrestricted non-commercial use, distribution, and reproduction in any medium, provided the original work is properly cited. with the influence of the monetary policy on bond price. It is because a change in monetary policy such as central bank rate, affects market interest rate, thereby influencing the bond price. However, according to Ellingsen and Soderstrom (2001) and Trinh et al., (2020), unanticipated monetary policy strongly influences bond yields for all maturities. This provides recurrent opportunities for bond traders to win or lose money.

In this paper, we conduct an empirical study on the effect of central bank independence (CBI) on bond yield. Figure 1 shows the average CBI and bond yield in 19 developing countries from 1991 to 2016 . From the graph, it is evident that an increase in CBI degree leads to a decrease in bond yields on average, across sample years. A decrease in bond yields results in lower borrowing cost for the government. Thus, it can be interpreted that a higher CBI or a credible central bank leads to better economic performance. On the effect of CBI on bond yield, Bodea and Hicks (2015) argue that bond yields decrease with higher CBI, suggesting that higher CBI reflects good governance, therefore, reducing investment risk. The average bond yield peaked in 1993 at around $28 \%$, whereas it dropped to approximately $8 \%$ in 2016 . 


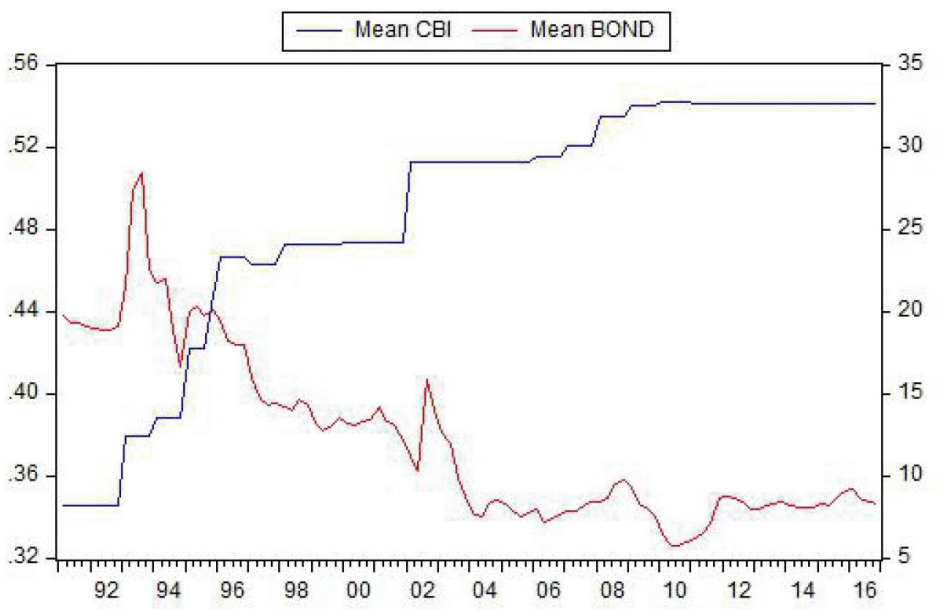

Figure 1: Average $\mathrm{CBI}$ and Bond Yield
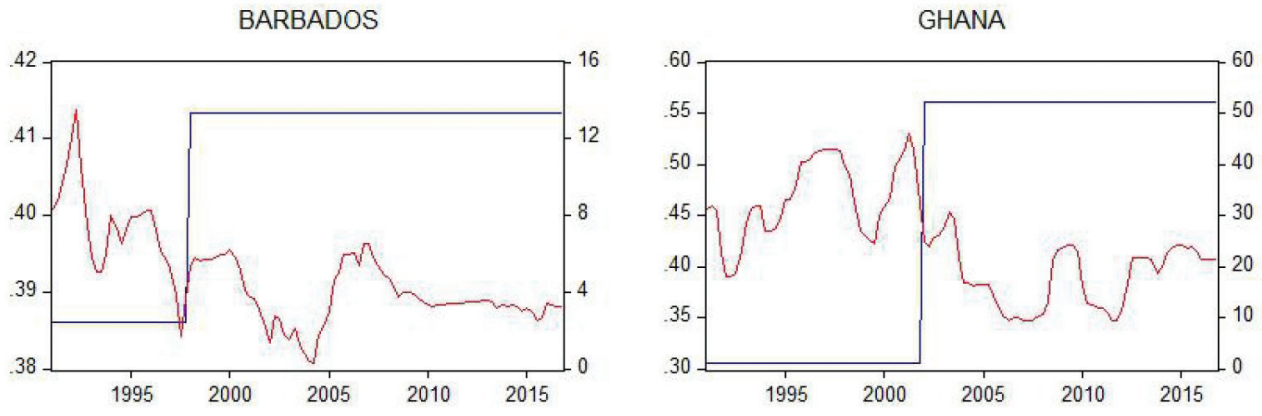

MALAYSIA

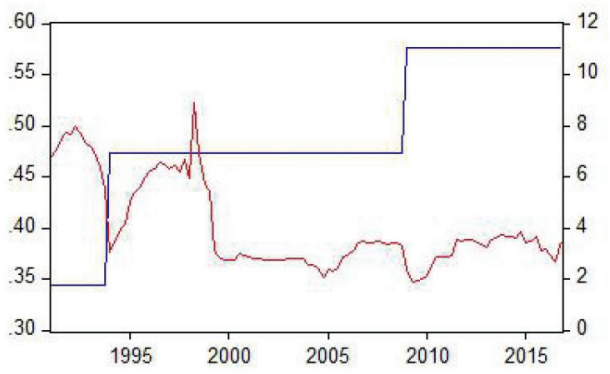

PHILIPPINES

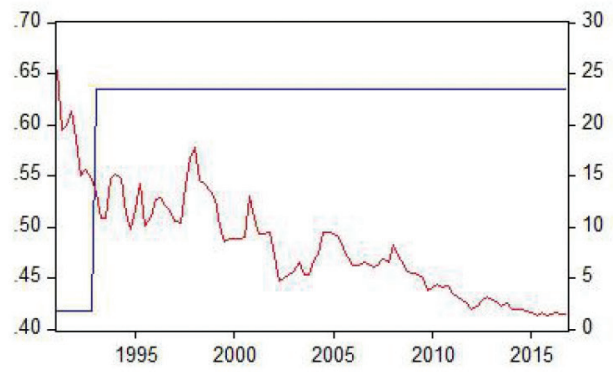

Figure 2: Average $\mathrm{CBI}$ and Bond Yield Country Level

The average CBI degree increased from 0.35 point in 1992 to 0.52 point in 2016. However, if we see the relationship between $\mathrm{CBI}$ and bond yield in a single country in Figure 2 , the magnitude of reduction in bond yield due to $\mathrm{CBI}$ is different for each country. For example, an increase of around 0.25 point in degree of CBI, reduces bond yield by $30 \%$ in Ghana. However, an increase of 0.2 point in the degree of $\mathrm{CBI}$, generates a reduction in bond yield by approximately $10 \%$ in Philippines. These differences show that there is heterogeneity in the effects between countries, caused by its own peculiar characteristics and dynamics, such as monetary policy and social economic characteristics. One common way to estimate country specific effect is performing a single country estimation. However, that approach might be inefficient if the reason of this heterogeneity can be modelled in panel estimation. It is because in the panel dataset, the cross country dimension can be utilised to identify the nature of economic mechanism. 
This paper is related to the recent development in dynamic heterogeneity of panel data econometric. First, by applying a panel VAR estimation for the sample of 19 developing countries with quarterly data from 1991 to 2016, we suggest that our result is biased. This bias is because of the fact that homogeneity assumption in the panel VAR model does not hold. Second, in order to prove the homogeneity assumption, we perform Chow and Roy-Zellner tests. Third, we apply mean group (MG) estimation for panel VAR as a solution for heterogeneity case in panel data. Fourth, we obtain poolable sample by splitting the sample into three subgroups.

After performing poolability test on panel VAR estimation, it was found that our models are not poolable. This implies that the panel VAR results are biased. We then did a MG estimation for panel VAR by estimating an individual VAR for each country then averaging the coefficients. We found that $\mathrm{CBI}$ leads to reduce in bond yield. Our result is robust since we find the same result for the three subgroups, i.e., CBI produces lower bond yield.

The rest of this study is organised as follows. Section 2 explores the literature review. Section 3 details out the construction methodology, models and data set that has been used. Section 4 and Section 5 discuss the empirical results and conclude the study, respectively.

\section{Literature Review}

The effect of monetary policy on asset prices has become one of the most interesting research in the area of macroeconomic policy since the last two decades. Kuttner and Posen (2010), have found that changes in monetary policy, including change of the central bank governor, can influence asset prices. They assessed the impact of change of the governor of the central bank on exchange rate and bond yield in 15 industrialised countries, covering years from 1974 to 2006 . To calculate the volatility of the exchange rate and bond yield, they used bootstrapped critical values instead of those derived from the normal distribution, and found that changes to the exchange rate and bond yield are not distributed normally and are skewed and leptokurtotic. They suggest that central bank appointments should change the markets through their effect on expected inflation and the interest rate. Their findings revealed that the exchange rate has a statistically significant response to the announcement of a new governor. However, they failed to establish a consistent and significant response with respect to effect on bond yield on the announcement of a new governor. One probable reason for that failure is the limited availability of daily bond yield data.

Moser and Dreher (2010) examined the effect of changing the governor of the central bank on the foreign exchange market, domestic stock market and sovereign bond spreads based on a data set for 20 emerging countries from 1992 to
2006. They suggest that financial markets react positively to a new central bank governor, if it conveys new information on the subject of future monetary policy. As inflation bias is determined by the degree of CBI, the public's perception of inflation expectation will be affected. Consequently, asset price should change to the extent of their sensitivity to inflation. Their results show that changing the governor of the central bank may also have a negative effect on the financial market if the investors think that the new governor of the central bank apparently suffers from a systemic credibility problem.

Bodea and Hicks (2014) examined the effect of the CBI index on 10-year domestic bond yield for a sample of 78 OECD and non-OECD countries from 1974 to 2007. They used Cukierman et al., (1992) index for CBI, as they were able to recognise the central bank's reforms for every country. They argue that a higher degree of legal CBI index is a signal which attracts investors, as CBI is granted via regular legislation and the risk of independence comes from implicit or explicit threats to amend the law. They determined that $\mathrm{CBI}$ has a negative relationship with 10-year bond rates in non-OECD countries, but $\mathrm{CBI}$ has no significant effect on 10-year bond rates for full sample countries. They argue that non-OECD countries may expect lower bond yield from greater CBI, when compared to other economies.

\section{Data and Methodology}

\subsection{Data}

The panel data used in this model covers 19 developing countries (Barbados, Bolivia, Egypt, Ghana, Kenya, Malaysia, Mexico, Nepal, Nigeria, Pakistan, Philippines, South Africa, Sri Lanka, Tanzania, Thailand, Trinidad and Tobago, Uganda, Uruguay and Zambia). Our dataset consists of 4 variables: CBI, bond yield, household consumption and investment. Quarterly data from first quarter of 1991 to fourth quarter of 2016 are employed.

For the measure of CBI, we follow the CBI index constructed by Cukierman et al., (1992). This index is based on the legal aspect of independence. The index is between 0 and 1 , with higher values denoting greater CBI for the legal index. The data relating to the CBI index is legal variable aggregate weighted and is obtained from Garriga's (2016) data set.

We use the government securities interest rate as a proxy for government bond yield, whereby data are retrieved from the International Financial Statistics (IFS) of the International Monetary Fund (IMF). We use household consumption and investment as a real economic activity following Claessens and Kose (2017), for reason that consumption is the largest share of output, while investment is the most volatile component of output (Beaudry et al., 2015). In terms of natural logarithm, the data is retrieved from the IFS of the IMF. 


\subsection{Econometrics Methodology}

The primary goal of this study is to observe the impact of CBI shock on bond yield, consumption and investment. Our empirical approach is based on panel VAR estimation which is useful for analysing the dynamics of the variables under consideration. In our panel VAR models, all variables are assumed to be endogenous and independent. We follow a panel VAR proposed by Canova and Ciccarelli (2013) and is represented as:

$$
y_{i t}=\alpha_{i t}+A_{i t}(') Y_{t-1}+u_{i t} \text { for } i=1, \ldots, N t=1, \ldots, T
$$

where $Y_{t}$ as the stacked model of $y_{i t}$, the vector of $G$ variables for each unit $i=1, \ldots, N$, i.e.,

$Y_{t}=\left(y_{1 t}^{\prime}, y_{2 t}^{\prime}, \ldots, y_{N t}^{\prime}\right)^{\prime}$ where $i$ is generic and indicate countries. $A()$ is a polynomial in the lag operator, $A_{i t}$ is the deterministic components, $u_{i t}$ is a $G \times 1$ vector of random disturbances.

Our panel VAR model to analyse the interaction among CBI, bond yield and economic activity include four endogenous variables: bond yield (Bond), CBI, household consumption (Cons), and investment (Inv).

$$
\begin{aligned}
\text { Bond }_{i t}= & \alpha_{1, i}++\sum_{j=1}^{k} a_{1, j} \text { Bond }_{i, t-j}+\sum_{j=1}^{k} b_{1, j} C B I_{i, t-j} \\
& +\sum_{j=1}^{k} c_{1, j} \operatorname{Cons}_{i, t-j}+\sum_{j=1}^{k} d_{1, j} \operatorname{Inv}_{i, t-j}+U_{1, i t} \\
\text { CBI } I_{i t}= & \alpha_{2, i}++\sum_{j=1}^{k} a_{2, j} \text { Bond }_{i, t-j}+\sum_{j=1}^{k} b_{2, j} C B I_{i, t-j} \\
& +\sum_{j=1}^{k} c_{2, j} \operatorname{Cons}_{i, t-j}+\sum_{j=1}^{k} d_{2, j} \operatorname{Inv}_{i, t-j}+U_{2, i t} \\
\text { Cons }_{i t}= & \alpha_{3, i}++\sum_{j=1}^{k} a_{3, j} \text { Bond }_{i, t-j}+\sum_{j=1}^{k} b_{3, j} C B I_{i, t-j} \\
& +\sum_{j=1}^{k} c_{3, j} \operatorname{Cons}_{i, t-j}+\sum_{j=1}^{k} d_{3, j} \operatorname{Inv}_{i, t-j}+U_{3, i t} \\
\text { Inv }_{i t}= & \alpha_{4, i}++\sum_{j=1}^{k} a_{4, j} \text { Bond }_{i, t-j}+\sum_{j=1}^{k} b_{4, j} C_{i, t-j} \\
+ & +\sum_{j=1}^{k} c_{4, j} \operatorname{Cons}_{i, t-j}+\sum_{j=1}^{k} d_{4, j} \operatorname{Inv}_{i, t-j}+U_{4, i t}
\end{aligned}
$$

\section{Empirical Results}

\subsection{Full Sample Countries Panel VAR}

First, we estimate the model to examine the interrelationship between CBI, bond yield, consumption and investment. We select lag 2 as the optimal lag based on Akaike information criterion. The panel VAR models in equations (2a) - (2d) are estimated in pooled least squared (POLS). The POLS estimator is known to be potentially biased in a dynamic panel setting if the coefficients on the endogenous variables differ across countries. We run the Chow test and Roy-Zellner test proposed by Baltagi (2008) to investigate the heterogeneity coefficients in the model. The null hypothesis confirms that the coefficients are the same for all cross countries. While the alternative hypothesis is the coefficients differ all across countries. The Chow and Roy-Zellner tests show that we reject the null hypothesis. This implies that coefficients in the panel VAR model contain cross country heterogeneity. One common way to solve the heterogeneity problem in the model is to perform the mean-group estimator proposed by Pesaran and Smith (1995) which is used by previous studies such as Gerlach and Assenmacher-Wesche (2008), Sa et al. (2011).

To analyse the effect of CBI on bond yield, the bond yield on consumption and investment, and CBI on consumption and investment, we will focus more on impulse response function. The results in Figure 3 shows that a shock oneunit positive innovation to the degree of $\mathrm{CBI}$ on bond yield is significant and a negative sign. In reaction to one positive innovation to the degree of CBI, the level of bond yield declines by $32 \%$ in period 6 , where from quarter eight onwards the negative response is getting lower. This reveals that a more independent central bank can reduce government borrowing cost. This occurs for the reason that higher CBI is a signal that a more credible central bank generates better future economic performance. In response to changes in one standard deviation of the bond yield, the consumption drops around $0.1 \%$ at quarter one but becomes positive at quarter two. Subsequently, from the fourth quarter onwards, the consumption response to bond yield is negative. This means that increased (decreased) bond yield generates lower (higher) consumption. Increased bond yield encourages the willingness to invest in government bond and therefore reduces current consumption (Sethi et al., 2019).

The influence of a one-unit innovation to the bond yield reduces investment significantly and reaches the lowest at period 10 , around $1.2 \%$. This implies that lower bond yield generates increased investment. Lower bond yield is a sign of a higher global sovereign rating, signifying lower investment risk. Consequently, it attracts investors thereby leading to an increase in investment. Shock one standard deviation of CBI reduces consumption around $0.6 \%$ from period 6 to 9 . After period 9, the negative effect is smaller. This may be caused by the lower wealth of the consumer, since higher CBI reduces bond yield leading to a lower disposable income. As a result, consumer spending decreases. In contrast, shock one standard deviation of CBI has a positive effect on investment and reaches the peak around $0.2 \%$ in period 4 . Higher CBI provides more transparency and credibility for the central bank and therefore, attracts more investment. 

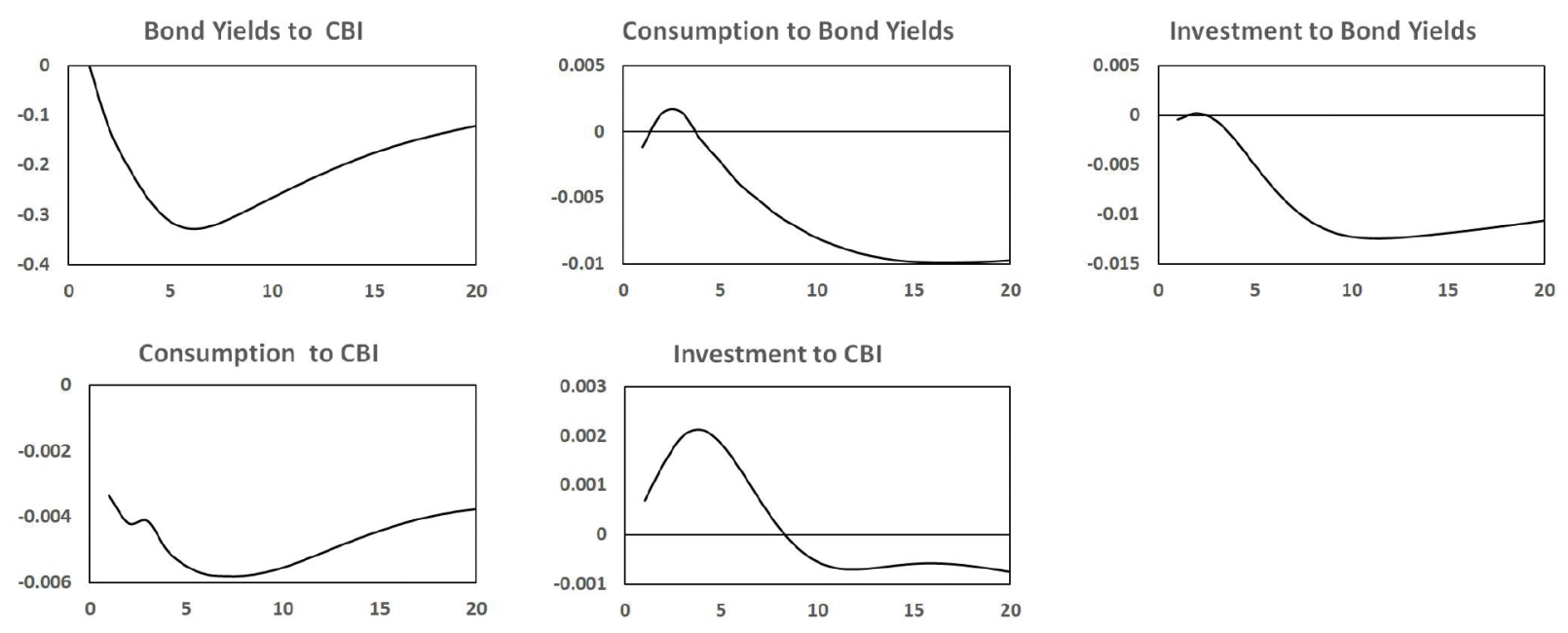

Figure 3: Impulse Response Function Mean Group Estimation.

Note: This estimation only averages the coefficient but not for confidence interval.

\subsection{Sub-sample Analysis}

We then split the sample of countries into three groups to obtain poolable group estimation. The first group includes Ghana, Malaysia, Nigeria, South Africa, Sri Lanka, Thailand and Zambia. The second group covers Egypt, Mexico, Nepal, Barbados, Pakistan in addition to Trinidad and Tobago. The last group involves Tanzania, Bolivia, Kenya, Philippines, Uganda and Uruguay. We then estimate the panel VAR for each group and explore whether the impact of CBI on bond yield, the bond yield on economic activity, CBI on economic activity differs among the three groups. Our approach of grouping the countries sample in three groups and estimating the panel VAR for each group robust regarding the result for the impact of CBI on bond yield, the bond yield on economic activity and $\mathrm{CBI}$ on economic activity. We are able to establish the poolable model for groups 1 and 2, but not for group 3. We then apply MG estimator for panel VAR on group 3. We differentiate for every group member using a degree of CBI, inflation, bond yield and sovereign risk. We do not find any difference in the average sovereign risk indices amongst the group. However, we find that in group 1, the average CBI is low, but the bond yield is high. In group 2, the average degree of $\mathrm{CBI}$ and bond yield is low, whereas, in group 3, the average degree of CBI and bond yield are high.

In this part, we analyse the effect of CBI on bond yield, bond yield on consumption and investment, and CBI on consumption and investment for the full sample and three sub-samples. By doing so, we address the principal aim of the thesis, i.e., to deal with heterogeneity among countries, since by splitting based on average CBI and bond yield rate, the sub-samples become more homogeneous groups than the entire countries sample.

Figure 4 reveals the impulse responses function (IRF) of CBI, bond yield, consumption and investment for the first group. Shock one-unit standard deviation of CBI will reduce the bond yield by $4 \%$ over four periods after the shock. The more independent the central bank, the lower the bond rate, which corresponds with our expectation. The effect of bond yield on consumption is positive. A change of $1 \%$ in bond yield increases consumption by $2.5 \%$ in one year. The consumption increase is due to bond yield which occurs throughout the period. This result is in line with the theory, that higher bond yield will increase disposable income and therefore, leads to higher consumption (2020). The same response is also revealed by investment in bond yield shock. Investment increases by $2.6 \%$ in period 4 for shock one standard deviation of bond yield and the response increases slightly for every period. This shows that higher bond yield attracts the public to invest more because they will receive higher returns. The effect of $\mathrm{CBI}$ shock on consumption is positive but it has a weak effect, as it takes 13 quarters for consumption to increase $1 \%$ from the CBI shock. However, we cannot see the response of investment to $\mathrm{CBI}$ shock because it is a very weak response. The small effect of CBI on consumption and investment considers the effect of monetary policy on economic activity via bond yield is weak.

Figure 5 reveals the IRF of CBI, bond yield, consumption and investment for the second group. Shock one-unit standard deviation of CBI generates lower bond yield of $3 \%$ in period 2. Subsequently, the impact is zero at quarter seven. From quarter eight onwards, the bond 
yield response to CBI shock is positive. Our finding shows that CBI is only effective in reducing bond yield in the short-run. Shock one standard deviation bond yield leads to an increase of $1 \%$ in consumption during period 5. The increase in consumption due to bond yield occurs throughout the period. The investment response to one percentage point relating to CBI shock is negative until period four, whereas the lowest is $0.2 \%$ in period 2 . The effect of CBI on investment is zero in period 5, however, it has a positive effect from quarter six onwards. The effect of
CBI shock on consumption is negative. Shock one standard deviation in the degree of CBI leads to a decrease of $0.3 \%$ in consumption in period four. The negative is greater for the later period. The investment response to CBI shock is negative and constant over the twenty periods. Shock one standard deviation in the degree of CBI produces a decrease of $0.1 \%$ to $0.2 \%$ in investment for all periods. The negative responses of consumption and investment to CBI shock reflect the weak effect of monetary policy on real activity via bond yield.
BOND YIELD TO CB
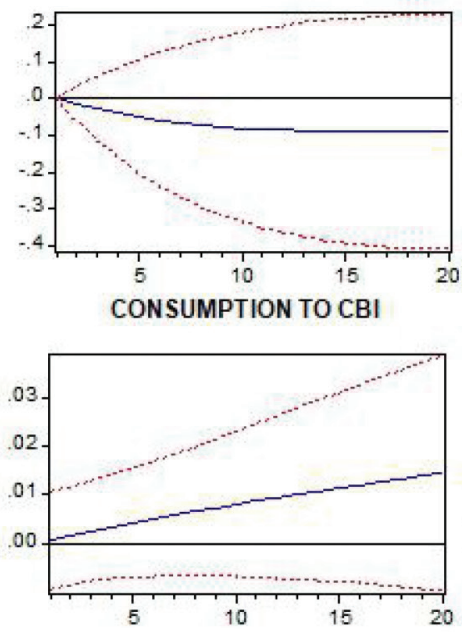

\section{CON SUMPTION TO BOND YIELD}

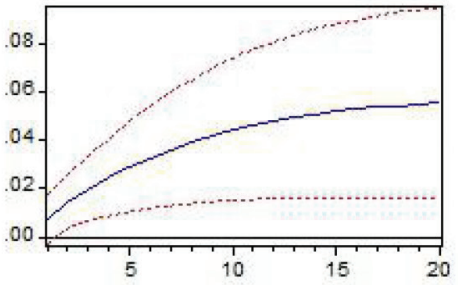

INVESTMENT TO CB|

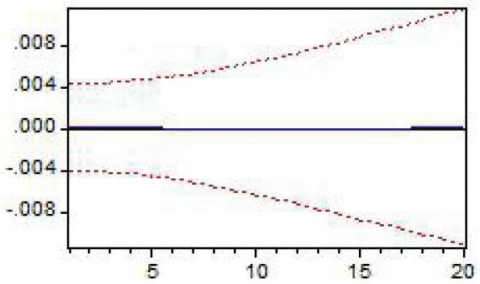

INVE STMENT TO BOND YIELD

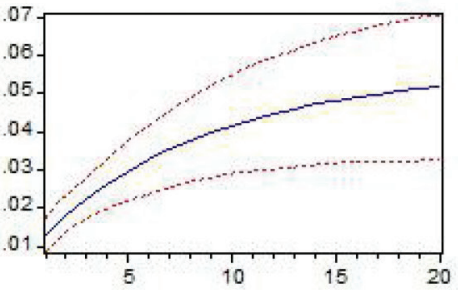

Figure 4: Impulse Responses Function Group 1

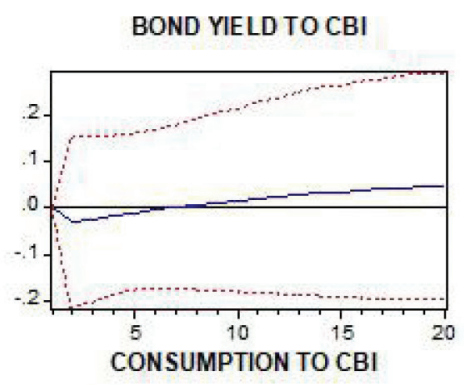

CON SUMPTION TO BOND YIELD
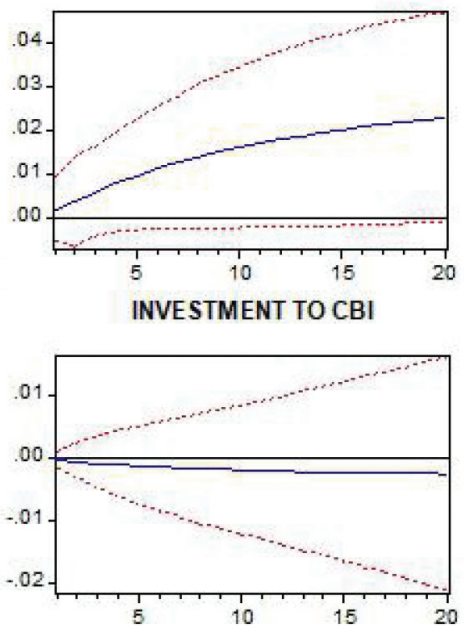

INVESTMENT TO BOND YIELD

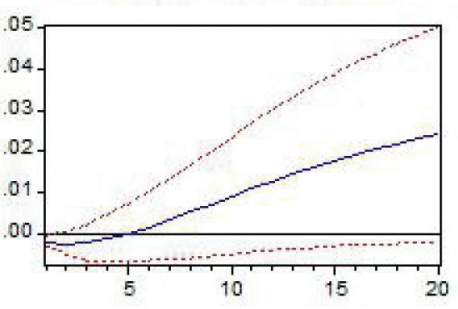

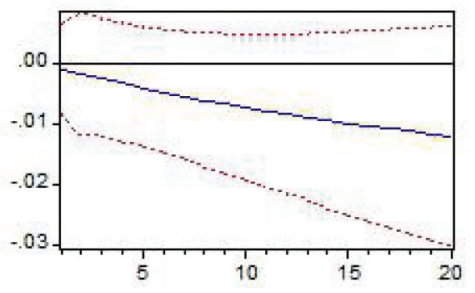

Figure 5: Impulse Responses Function Group 2 
In group 3, we apply mean-group estimation by averaging the coefficient for the 7 countries sample for the IRF of CBI, bond yield, consumption and investment. The results are shown in Figure 6. A one-unit positive shock innovation to the degree of CBI on bond yield is significant and a negative sign. In reaction to one positive innovation to the degree of CBI, the level of bond yield declines by $8.6 \%$ in period 6 , from quarter eight onwards the response toward the initial value. This result corresponds with our expectation that $\mathrm{CBI}$ is an essential factor for reducing bond yield. In response to a 1 percentage point change in the bond yield, the fall in consumption starts in the first quarter and reaches the lowest at quarter three, around $0.18 \%$, the response towards the initial value at period 10 . Then, from the eleventh quarter onwards, the consumption response to bond yield is positive. This means that when bond yield increases, the public will spend more to buy bonds, reducing consumption in the short-run. However, after ten quarters, public spending begins to rise because they have more income from the bond returns. The influence of a one-unit innovation to the bond yield increases investment by $0.18 \%$ in the first quarter, although starting from the third quarter, the investment response is negative and reaches its lowest point in period 9 , to around $0.5 \%$. This shows that investors will respond directly to increasing bond yield. Shock one standard deviation of CBI reduces consumption by around $0.2 \%$ in period 1 . After that, the negative effect is greater. Shock one standard deviation of $\mathrm{CBI}$ has a negative effect on investment and reaches the lowest point, at around $0.5 \%$ in period 8 . Subsequently, the effect remains stable. The negative effect of CBI on consumption and investment via bond yield may be caused by the strong negative effect of bond yield on consumption and investment as per Figure 6.

\subsection{Comparison Sub-sample Groups}

First, we describe shock as a one-unit positive innovation to the degree of CBI on bond yield for four different groups. In response to one positive innovation to the degree of $\mathrm{CBI}$, the level of bond yield declines with the highest for group 3 , followed by the full sample and group 1, while for group 2 the response is zero. This evidence suggests that investors reward a credible independent central bank as higher CBI reflects good governance, thereby, reducing investment risk. Lower government bond yields are perceived by investors as a signal of improvement in public finances. Bodea and Hicks (2014) indicated that investors are eager to enter countries that appear to be democratising early and that legal CBI can reduce borrowing costs even for such countries. Pastor and Maxfield (1999) stated that CBI as a signal of more credible economic policies for international investors. They arrived at the conclusion that higher levels of CBI have a positive and significant effect on investment in developing countries. Now, we compare the effect of CBI on the bond yield on three different groups. The negative effect of CBI on bond yield is strong for the group with a high CBI degree but not with high bond yield. The negative relationship between both variables is weak for group countries with a low degree of CBI and high bond yield. For group countries with a low degree of CBI and low bond yield, CBI reduces bond yield only in the short-run.
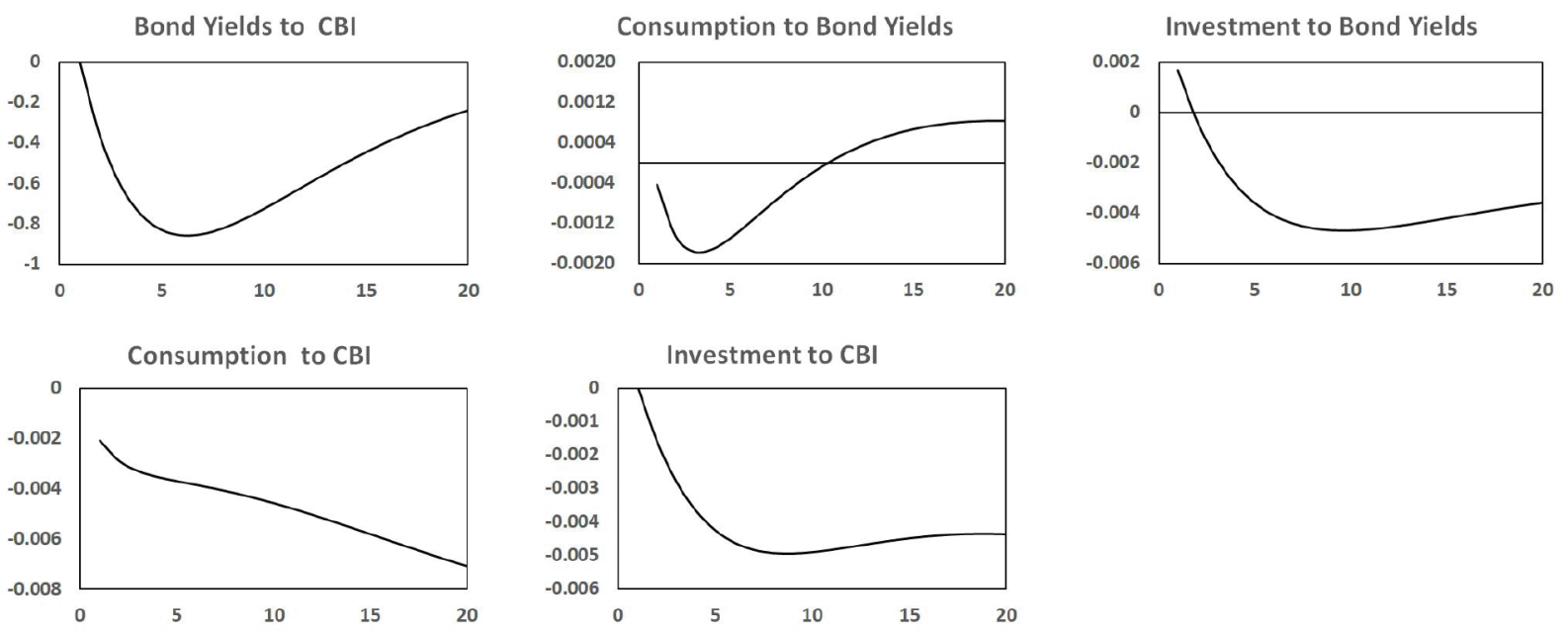

Figure 6: Impulse Responses Function Group 3 
The impact of a one-unit positive innovation to the bond yield on consumption and investment will be explained hereafter. For consumption, in response to a 1 percentage point change of the bond yield, consumption rises rapidly for groups 1 and 2, where the magnitude for group 1 is around double than group 2. An increase in the interest rates on government bonds generates higher disposable income, therefore, increasing public consumption. The consumption response on bond yield is around zero for group 3 for the entire period. However, for the full sample, we can find the negative effect of bond yield on consumption after four quarters. The negative effect might be caused by high inflation in the sample countries. The higher inflation rate will lower the value of private assets which is interpreted as negative income by consumers and in turn reduces consumption (Hansen, 1996). The different responses of consumption to bond yield shock could be caused by the level of inflation in the sample countries.

The influence of a one-unit innovation to the bond yield raises investment significantly in group 1 and group 2 but is negative for group 3 and the full sample. The increase in investment with higher interest rates on government bonds would be required in order for investors to hold the additional bonds. Government bond yield can be seen by investors from two perspectives. First, investors see increase or reduction in bond yield as if bonds are seen as a component of asset wealth. Second, if the reduction in bond returns is perceived as a signal of improvement in public finance, then investors will allow investment to increase above its equilibrium because the risk is lower.

We now consider the effect of $\mathrm{CBI}$ on consumption via bond yield. The consumption response to CBI shock is negative for all groups except on group 1. For group 1, which comprises high bond yield countries, the positive effect of $\mathrm{CBI}$ on consumption is the impact of high disposable income due to high bond yield. Higher bond yield produces greater returns for consumer and therefore, will encourage the public to spend on consumption. Conversely, the negative effect of CBI on consumption for group 2 is caused by the positive view of better future economic performance, due to a higher CBI. As a result, a higher degree of CBI will encourage the public to buy government bonds, thereby reducing consumption. For group 3 and the full sample, higher CBI causes lower bond yield thus, reducing public disposable income. Lower disposable income results in a drop in consumption.

Meanwhile, response of investment to CBI shock. Investment response to CBI shock is neutral for group 1, this means that $\mathrm{CBI}$ is not significantly affecting investment. This finding is in line with the findings by Claessens and Kose (2017), who stated that the indirect effect of monetary policy on economic activity via the interest rate channel is weak in an undercapitalised financial system. The negative response of investment to CBI shock is shown by group 2 and group 3. However, the impact on group 3 is almost twice as that on group 2 . This might be caused by more financial friction in group 3 than group 2. As stated by Bernanke and Gertler (1995) the indirect effect of monetary policy on investment via the interest rate is large in countries with market imperfection and financial friction. In the full sample countries, the positive response of investment to CBI shock appears until the beginning of quarter eight but is negative from period 8 onwards. This implies that increasing CBI successfully attracts investors only at the beginning. However, CBI losses the effectiveness to enhance investment because it has diminishing marginal returns (Bodea and Hicks, 2014).

\section{Conclusion}

This paper provides empirical analysis of CBI and economic activity via bond yield. Our results, which use a panel VAR, specify that the model contains heterogeneity across countries. We then apply a mean-group panel VAR by averaging the individual VAR for all of the samples. Mean-group for panel VAR estimation only averages the coefficient but not for standard error and t-statistic. The results reveal that $\mathrm{CBI}$ is effective in reducing bond yield to the maximum till 6 years after the shock. Shock one standard deviation bond yield has a negative effect on consumption and investment. We determine that CBI has a contradictory effect on real activity, a negative effect on consumption but a positive influence on investment for the first two years after the shock. We then divide our sample into three groups to make the homogeneous sub-samples. The results illustrate that $\mathrm{CBI}$ lowers bond yield for all groups, however, for group 2 the positive response occurs after period 8. Meanwhile, the response of economic activity to bond yield also varies for all three groups. We find a positive response for both consumption and investment for groups 1 and 2. This means that higher bond yield leads to higher consumption and investment. However, for group 3, the shock on bond yield will reduce both consumption and investment, nevertheless, the effect is extremely small.

\section{References}

Baltagi, B. (2008). Econometric Analysis of Panel Data (5th ed.). Hoboken, NJ: John Wiley \& Sons.

Beaudry, P., Moura, A., \& Portier, F. (2015). Reexamining the cyclical behavior of the relative price of investment. Economics Letters, 135, 108-111. https://doi.org/10.1016/j. econlet.2015.05.011

Bernanke, B. S. and Gertler, M. (1995). Inside the black box: The credit channel of monetary policy transmission. Journal of Economic Perspectives, 9(4), 27-48. https://doi.org/10.1257/ jep.9.4.27 
Bodea, C., \& Hicks, R. (2014). International finance and central bank independence: Institutional diffusion and the flow and cost of capital. The Journal of Politics, 77(1), 268-284. https:// doi.org/10.1086/678987

Bodea, C., \& Hicks, R. (2015). Price stability and central bank independence: Discipline, credibility, and democratic institutions. International Organization, 69(1), 35-61. https:// doi.org/10.1017/S0020818314000277

Canova, F., \& Ciccarelli, M. (2013). Panel vector autoregressive models: A survey. Advances in Econometrics, 31. https://doi. org/10.1108/S0731-9053(2013)0000031006

Carstens, A., Jacome H., \& Luis I. (2005). Latin American central bank reform: Progress and challenges. IMF Working Paper, WP/05/114. Washington, DC: International Monetary Fund.

Claessens, S., \& Kose, M. A. (2017). Asset prices and macroeconomic outcomes: a survey. Policy Research Working Paper No. 8259. Washington, DC: The World Bank.

Cukierman, A., Webb, S. B., \& Neyapti, B. (1992). Measuring the independence of central banks and its effect on policy outcomes. The World Bank Economic Review, 6(3), 353-398. https://doi.org/10.1093/wber/6.3.353

Ellingsen, T., \& Soderstrom, U. (2001). Monetary policy and market interest rates. American Economic Review, 91(5), 15941607. 10.1257/aer.91.5.1594

Garriga, A. C. (2016). Central bank independence in the world: A new data set. International Interactions, 42(5), 849-868. https://doi.org/10.1080/03050629.2016.1188813

Gerlach, S., \& Assenmacher-Wesche, K. (2008). Financial structure and the impact of monetary policy on asset prices. CFS Working Paper Series No. 2008/30. Centre for Financial Studies (CFS).

Hansen, H. J. (1996). The impact of interest rates on private consumption in Germany. Discussion Paper No. 3/96. Deutsche Bundesbank, Frankfurt, Germany.

Kuttner, K. N. (2001). Monetary policy surprises and interest rates: Evidence from the fed funds futures market. Journal of
Monetary Economics, 47(3), 523-544. https://doi.org/10.1016/ S0304-3932(01)00055-1

Kuttner, K. N., \& Posen, A. S. (2010). Do markets care who chairs the central bank? Journal of Money, Credit and Banking, 42(23), 347-371. 10.1111/j.1538-4616.2009.00290.x

Moser, C., \& Dreher, A. (2010). Do markets care about central bank governor changes? Evidence from emerging markets. Journal of Money, Credit and Banking, 42(8), 1589-1612. https://doi. org/10.1111/j.1538-4616.2010.00355.x

Nurbayev, D. (2015). Independence and transparency of the central bank of Kazakhstan. The Journal of Asian Finance, Economics, and Business, 2(4), 31-38. https://doi.org/10.13106/jafeb.2015. vol2.no4.31.

Pastor Jr., M., \& Maxfield, S. (1999). Central bank independence and private investment in the developing world. Economics \& Politics, 11(3), 299-309. https://doi.org/10.1111/1468-0343.00063

Pesaran, M., \& Smith, R. (1995). Estimating long-run relationships from dynamic heterogeneous panels. Journal of Econometrics, 68(1), 79-113. https://doi.org/10.1016/0304-4076(94)01644-F

Sá, F., Towbin, P., \& Wieladek, T. (2011). Low interest rates and housing booms: The role of capital inflows, monetary policy and financial innovation. Globalization Institute Working Papers No. 79. https://doi.org/10.2139/ssrn.1765853

Sethi, M., Baby, S., \& Dar, V. (2019). Monetary policy transmission during multiple indicator regime: A case of India. Journal of Asian Finance, Economics and Business, 6(3), 103-113. https:// doi.org/10.13106/jafeb.2019.vol6.no3.103

Trinh, Q. T., Nguyen, A. P., Nguyen, H. A., \& Ngo, P. T. (2020). Determinants of Vietnam government bond yield volatility: A GARCH Approach. Journal of Asian Finance, Economics, and Business, 7(7), 15-25. https://doi.org/10.13106/jafeb.2020. vol7.no7.015

Yuliadi, I. (2020). An analysis of money supply in Indonesia: Vector autoregressive (VAR) approach. Journal of Asian Finance, Economics, and Business, 7(7), 241-249. https://doi. org/10.13106/jafeb.2020.vol7.no7.241 